\title{
An maith leat an Ghaeilge? An analysis of variation in primary pupil attitudes to Irish in the Growing Up in Ireland study
}

\author{
Dr Ann Devitt, School of Education, Trinity College, Dublin. Ann.Devitt@tcd.ie \\ Dr Joe Condon, School of Mathematical Sciences, Dublin Institute of Technology. \\ joe.condon@dit.ie
}

Gene Dalton, School of Education, Trinity College, Dublin. daltonge@tcd.ie

Jane O'Connell, School of Education, Trinity College, Dublin.otooleja@tcd.ie

Melanie Ní Dhuinn, School of Education, Trinity College, Dublin.

mnidhuin@tcd.ie

This paper presents an analysis of primary schoolchildren's attitudes to the Irish language, Gaeilge, in the context of national policy in the Republic of Ireland. In particular, the study examines the factors (social, cultural, cognitive and organisational) that may be related to a pronounced excess in disengagement with Irish over and above general engagement with schooling. The data derives from the 9 year old child cohort of the national longitudinal study of children, the Growing Up in Ireland (GUI) survey. Unlike previous findings in relation to general engagement with school, excess disengagement with Irish is not found to be related to socio-economic or ethnic factors, factors related to teacher profile, training, self-efficacy or style or school ethos. As expected, children with less exposure to spoken Irish in school or at home are more likely to show excess disengagement with the language. Literacy activity, special education needs and school patronage are also found to be related to excess disengagement. Significant random effects indicate the importance of the individual teacher and school in the development of pupil engagement with Irish. The current study presents a timely perspective on attitudes to Irish among the younger population and possible implications for policy.

Keywords: Irish language, motivation, minority languages, bilingualism, biliteracy 


\section{Introduction}

The Irish language, Gaeilge, is the first official language of the Republic of Ireland and an official working language of the European Union since 2007. While the majority of people in Ireland speak English as a first language, there is a small minority for whom Irish is the language of their community. It is spoken as a household or community language by approximately $3 \%$ of the population of the island of Ireland. The census figures report that approximately $42 \%$ of the population speak Irish but only 1 in 20 of the population use Irish on a daily basis outside the school system (CSO, 2011). Watson and Nic Ghiolla Phádraig (2011) estimate the number of people who can engage in all or most conversations in Irish to be closer to $16 \%$. Within a national context which over the last 20 years has rapidly become linguistically and ethnically diverse with over 180 languages spoken in Ireland today (CSO, 2011) with continued positive migration flows from non Irish-nationals throughout the ecomonic downturn, there is a picture of declining use and proficiency of Irish in traditionally Irish speaking Gaeltacht areas (Ó Giollagáin \& Mac Donnacha, 2008) and in the education system (Harris, Forde, Archer, Nic Fhearaile, \& O’Gorman, 2006b). However, the huge majority of the population (89\%) remains positively disposed to the language (MORI Ireland, 2005).

In terms of language policy, the maintenance and growth of the language across the country has been largely reliant on the education system since the 1930s (Harris, 2007). Indeed, the school system is the principal means by which people in Ireland come into contact with the Irish language (Murtagh, 2007). Most schools in Ireland use English as the medium of instruction, with Irish being taught as a second language in a discrete language lesson every day. Irish is a compulsory subject in Irish schools with pupils at primary and secondary level spending between three and four hours per week 
studying the language. Over recent years there has been a rapid expansion of Gaelscoileanna (i.e. Irish immersion primary schools), where Irish is the medium of instruction (Parsons \& Lyddy, 2015). These schools have been growing in popularity since the 1980s and have demonstrated considerable success in maintaining a high standard of Irish (Harris et al., 2006b). However, concerns about proficiency in the language were to the fore in Harris et al.'s longitudinal study of achievement in Irish, (Harris et al., 2006b) which found a significant drop in standards of proficiency across Irish primary schools since the 1980s: for example in the category of listening comprehension the percentage of children achieving mastery in 1985 was $48 \%$, dropping to $8 \%$ in 2002 . At present it is the school-going population who report most use of Irish on a daily basis (CSO, 2011) and this consistent decline in proficiency levels is of concern.

The recent 20-Year Irish Language Strategy (Government of Ireland, 2010) aims to shift the locus for the language from the school alone to the wider community to generate a language revival increasing the number of daily speakers of Irish to 250,000 . Education is one of the nine actions identified in the strategy as it recognises that the education system is one of the main methods of promoting the Irish language. The formal education system structures afford opportunity to further language acquisition through curriculum, availability of resources, teacher education and standardised assessment. In addition to the formal education system however, the strategy aims to promote opportunities for children and families to engage naturally through the medium of Irish outside of the school context, building sustainable language communities. This extension of Irish language policy outside of the education system is to be welcomed but its implementation and impact may be limited by the recent challenging economic climate. 


\section{Motivation and Attitudes to the Irish language}

There is a general consensus that the concept of attitude and motivation in language learning is complex but strongly correlated with successful language acquisition (Dörnyei, 2001; Ellis, 1997; Lightbown \& Spada, 2001). In the case of Irish, a distinction must be drawn between attitude to the language and attitude to learning the language. As noted above, representative samples of the Irish adult population tend to be very positively disposed towards the Irish language (MORI Ireland, 2005). Higher social class and more positive attitudes to Irish appear to be strongly associated (Committee on Irish Language Attitudes Research (CILAR), 1975; Pádraig Ó Riagáin, 2007), however, the nature of this relationship is contested (Watson \& Nic Ghiolla Phádraig, 2011). However, as noted above, this general positivity does not always translate into language proficiency or use. In a study of school-leavers, Murtagh (2007) found that the motivation to learn Irish was strongly related to the language medium of the school with students in English medium-schools at best neutral and at worst negative towards learning Irish. Motivation was strongly correlated with achievement levels in spoken and written Irish. In this study, the learners tend to be instrumental rather than integrative in their motivation to learn the language. Watson and Ó Riagáin (2011) develop an interesting cultural capital argument in relation to this linked to the historical role of Irish competence for access to third level education and in securing a civil service or teaching post.

As regards the focus for this paper, children of primary school age, Harris and Murtagh's Twenty-Class Study (Harris \& Murtagh, 1999) is perhaps the most comprehensive body of research to date on primary school children's attitudes towards the Irish language in English-medium primary schools. In a nationally representative sample of 20 sixth-grade classes, approximately half of children demonstrated a positive 
attitude to Irish. In terms of the relationship between proficiency and attitude, children with a more positive attitude demonstrated higher proficiency in Irish. In terms of teaching approach, there was a statistically significant correlation between a communicative teaching approach and positive attitudes towards the language.

This study led to the introduction of a new communicative curriculum for Irish in primary schools in 1999 (National Council for Curriculum and Assessment, 1999). This curriculum was strongly communicative in nature in order to enable the child to use the language in a natural way. In 2008 a review of this new curriculum (National Council for Curriculum and Assessment, 2008) reported that the new curriculum had led to an increase in children's enjoyment of Irish lessons and an increase in their sense of pride in the language.

Building on the NCCA review, McCoy et al (2012) used data from the Growing Up in Ireland longitudinal study to look at teaching and learning in the primary schools from both student and teacher perspectives. The study found that the children's attitudes were least positive to Irish relative to Reading and Mathematics, with only a fifth of children always liking it. Boys were more disengaged than girls, with approximately one third of boys never liking Irish compared to approximately a quarter of girls.

\section{Motivation and Identity}

Motivation for language learning is additionally complex as it includes a component of identity and identification with another linguistic group (Gardner \& Lambert, 1972, p. 135). In the Irish context, the association of Irish with particular political and religious communities, particularly in Northern Ireland, appears in the past to have had a strong

impact on individual attitudes to learning the language (Ó Riagáin, 2007). Furthermore, the degree to which the Irish language and/or Irish language proficiency is associated 
with "being Irish" is a contested space in the population of the island of Ireland (Fahey, Hayes, \& Sinnott, 2005; Ó Riagáin, 2007) which may further complicate the relationship between attitudes to Irish and identification with Irish people or Irishness.

\section{Motivation and School Context}

Other key contributors to language learner motivation are external agents, in particular teachers (Dörnyei, 2005; Williams \& Burden, 1997). The role of the teacher in generating a low stress, highly motivating learning context has also been identified as central to facilitating language learning and encouraging learner autonomy (Dörnyei \& Csizér, 1998; Littlewood, 1984; Ushioda, 1996). In the Irish context, the attitudes of teachers to the teaching and learning of Irish has seen a decline (Harris et al., 2006b). The Harris et al. longitudinal study gives some very insightful comparisons between teacher attitudes in 1985 and 2002. The data would suggest that while in 2002 the majority of children in primary school classrooms had teachers who were favourable towards Irish, there had been a decrease of almost $9 \%$ since 1985. The percentage of children whose teachers derive satisfaction from teaching Irish has fallen by $25 \%$ in that time period, with a corresponding increase of $16 \%$ in those whose teachers reported dissatisfaction.

More recently, Ó Laoire (2007) published a study on student teacher attitudes to Irish. He found that the majority of student teachers showed a positive attitude towards Irish, which is in line with previous research (Committee on Irish Language Attitudes Research (CILAR), 1975; P Ó Riagáin \& Ó Gliasáin, 1984, 1994). However, Ó Laoire suggests that this attitude is primarily a functional one relating to doing well in exams or getting a job. He claims that the positive attitude of these student teachers is a "passive 
stance rather than a proactive attitude", as there is no evidence that they are taking active steps to promote Irish speaking (p.181).

In relation to classroom environments for Irish, the National Inspectorate have issued two reports in recent years which deal with Irish in the primary school. A dedicated report in 2007 describes findings from an investigation of Irish teaching and learning in 40 schools and 159 classrooms in 2005 (Inspectorate, Department of Education and Science, 2007). The report found that $23 \%$ of teachers had unsatisfactory levels of Irish (3\% with significant difficulties and $20 \%$ with scope for improvement in their spoken Irish). The standard of teaching and learning was poor or fair in half the classes observed, with only $6 \%$ of classes showing excellent teaching. The report notes the link between language and teaching competencies in that teachers with a stronger competence in Irish often displayed better teaching methodologies. A more recent Chief Inspector's report for 2010-2012 describes findings for the teaching of Irish that are significantly less positive than those for Reading and Mathematics (Inspectorate, Department of Education and Skills, 2013). Standards of Irish teaching were deemed unsatisfactory in one fifth of lessons, while Irish learning outcomes were unsatisfactory in one quarter of all lessons.

\section{Bilingualism and the Continua of Biliteracy}

One of the main motivations for carrying out this study was to explore the relationship between languages and between language competencies and attitudes towards the learning of Irish. This dimension of the study takes as its theoretical basis the Common Underlying Proficiency model of language competence (Cummins, 1979) whereby language competencies may transfer across languages at a given threshold of competence and, in relation to the written word, Hornberger's (2004) Continua of Biliteracy. This framework offers a means of conceptualising the multiple and inter- 
related dimensions of literacy and language across and within languages. Over the last 20 years, the Irish population has undergone a demographic transformation from a predominantly homogeneous society to one where approximately $10 \%$ of residents are non-Irish citizens from over 180 countries (Conrick, 2009). This increase in cultural and linguistic diversity presents both an opportunity and a challenge for the Irish language in Ireland. Recent work in the Basque Country and Catalunya have explored the language attitudes of diverse populations in bilingual contexts (Huguet, 2006; Ibarraran, Lasagabaster, \& Sierra, 2008; Lasagabaster \& Huguet, 2007). The findings of these studies would suggest that language attitudes are not stable across linguistic and culturally diverse populations but nor are they stable over time with increases in positive attitudes in evidence after a period of integration within school and society (Ianos, Huguet, Janés, \& Lapresta, 2015). In terms of literacy practices, Hornberger's (2004) Continua provide a framework for exploring the range of relations that may exist between literacy practices across different language, proficiency levels and contexts. Martin-Jones' ethnographic study of young adult bilinguals in Wales for example emphasised the diversity of digital and print literacy practices across languages which the participants engaged in outside the school context (Martin-Jones, 2009). This study aimed to explore inter- and intra-language factors impacting on attitudes towards Irish, looking at multilingual competencies of the child and engagement with language skills generally, in particular literacy.

The study presented here uses the national longitudinal study of children, the Growing Up in Ireland Study (Green et al., 2010), to investigate socio-economic, linguistic and ethnic identity, parent, teacher and school factors in relation to 9 year old children's attitude towards the Irish language. This research reported here is novel in providing the perspective of the learners aligned with their teachers and parents or caregivers as 
represented in the GUI data to explore attitudes to Irish specifically as distinct from schooling in general.

\section{Data Analysis}

The Growing Up in Ireland study represents the first longitudinal study of the wellbeing and development of children in Ireland and is conducted by the ESRI and Trinity College Dublin. The full GUI dataset is extremely rich, including an infant and a child cohort, currently in two waves of data collection, with multiple informants (child, caregivers and educators). Wave 1 of The Growing Up in Ireland Survey (9 year cohort) consisted of a stratified random sample of 8568 nine year old students from 910 schools throughout Ireland conducted between 2007 and 2008. The Wave 1 data used in this study is made available through the Central Statistics Office subject to the Statistics Act, 1993 and the authors of this paper were appointed Officers of Statistics for the duration of this research project.

This analysis was focussed on one of the variables recorded: the response of the student to the question, "Do you like Irish?". The student selected one response from three offered: "Always like it"; "Sometimes like it"; "Never like it". The focus of this paper in on attitudes of school children towards the Irish language. Therefore, any references to engagement with the Irish language are to be taken as referring to affective engagement with Irish and not directly to the behavioural or cognitive dimensions of engagement (Jimerson, Campos, \& Greif, 2014).

This variable has previously been considered as part of a more widely focussed study by McCoy et al. (2012). In that study binary logistic regression was used to model low levels of engagement with school (three measures) as well as engagement with three core subjects in the Irish primary educational system, i.e. Reading, Mathematics and 
Irish. The findings of McCoy et al. (2012) indicated the importance of certain common factors across the various measures of educational engagement they examined.

However, levels of engagement with the subject Irish were not perfectly correlated with levels of engagement with other aspects of the primary education system. In particular, $36 \%$ of students had a less favourable attitude to Irish than they had for school. This compared with corresponding values of $17 \%$ and $9 \%$ for Mathematics and Reading respectively. Clearly, there was evidence of what can be termed 'excess disengagement' with Irish compared to other core subjects. The purpose of this study was to identify what factors, if any, are related to this specific form of excess disengagement.

\section{Method}

Ordinal logistic regression was used to model the probability of a student choosing one of the possible responses to the dependent variable. Fifty different factors were considered for inclusion in the regression model. As the focus in this analysis was on identifying factors related to excess disengagement with Irish, those related to more general forms of educational engagement needed to be controlled for. Thus, factors related to engagement with school, teacher, Reading and Mathematics were included as dependent variables in the model.

Statistical model building techniques using a stepwise AIC algorithm supplemented with likelihood ratio tests were used to identify factors significantly related to the response. Only statistically significant factors were retained in the model. Two way interactions between factors were also considered where there were sufficient numbers of observations to permit stable estimates of the interaction effects to be obtained.

These data were structured in a multilevel hierarchy, with students clustered within teachers (classrooms) and teachers clustered within schools. Random effects at both the teacher and school levels were used to model correlation within clusters. Statistically 
significant random effects at a level in the hierarchy would indicate the importance of unmeasured (latent) factors at this level related to the dependent variable (Agresti, 2010). The statistical significance of the random effects was established using likelihood ratio tests, with appropriate p-value adjustments (Molenberghs \& Verbeke, 2007; Stram \& Lee, 1994).

Fitting ordinal logistic regression models with two random effects and a large number of clusters presents a challenge to the currently available software. Therefore, the models were fitted using both the 'ordinal' package in R (Christensen, 2013) and by Proc Glimmix in SAS (SAS Institute Inc., 2011). The results were found to be consistent between the two software platforms.

\section{Results}

The parameter estimates from fitting ordinal logistic regression to these data are shown in Table 1, along with their estimated standard errors, p-values and odds ratios (OR). The OR can be interpreted as effect sizes, with large OR values being indicative of a stronger relationship between the factor and dependent variable. In this modelling context, OR values of 2 or more may be considered relatively strong effect sizes; OR values between 1.5 and 2 as moderate; and OR values between 1 and 1.5 as modest.

\section{Student level factors}

Disengagement with school was seen to have a strong effect size relationship with excess disengagement (sometimes like school/always like school: OR=2.3, 95\% CI 2.12.6; never like school/always like school: $\mathrm{OR}=5.2$, 95\% CI 4.1-6.7). In general, engagement with Mathematics was not seen as related to excess disengagement, but is strongly related in the case of all-girls schools $(\mathrm{OR}=2.4,95 \% \mathrm{CI}=1.5-3.8)$ or for students who are in receipt of resource hours $(\mathrm{OR}=1.9,95 \% \mathrm{CI}=1.2-3.2)$. Engagement 
with Reading (OR=1.7, 95\% CI=1.6-1.9) and teacher ( $\mathrm{OR}=1.6,95 \% \mathrm{CI}=1.4-1.7)$ were found to have moderate effect sizes.

Less exposure to spoken Irish language was found to be strongly related to excess disengagement. Students who attended English language schools (94\% of the primary school-going population) were significantly more likely to display excess disengagement compared with students who attended Irish language schools $(\mathrm{OR}=3.3$, 95\% CI=2.6-4.1) or with students who attended schools located in Irish speaking communities $(\mathrm{OR}=1.9,95 \% \mathrm{CI}=1.2-2.8)$. There was a moderate relationship between a lack of exposure to the Irish spoken at home and the dependent variable $(\mathrm{OR}=1.6,95 \%$ $\mathrm{CI}=1.4-1.8)$.

Literacy engagement was also found to be related to the dependent variable with those students who read for pleasure less than once a week having a higher odds of excess disengagement compared to those who read for pleasure daily $(\mathrm{OR}=1.4,95 \% \mathrm{CI}=1.2$ 1.7). Reading or not reading with parents $(\mathrm{OR}=1.1,95 \% \mathrm{CI}=1-1.2)$ and amount of screen time (e.g. $>3$ hours per day versus less than 1 hour) $(\mathrm{OR}=1.3,95 \% \mathrm{CI}=1.2-1.6)$ were also found to be statistically significant with modest effect sizes.

In general, students in receipt of resource hours were found to have an increased odds of excess disengagement, although this relationship was found to vary with the level of engagement with Mathematics (e.g. OR=2.2 controlling for sometimes or never likes Mathematics to $\mathrm{OR}=1.1$ always likes Mathematics).

Just as interesting as the factors that were found to be related to the dependent variable were the factors for which no evidence of such a relationship was found. These included: various measures of the socio-economic status of the household (including income); household composition (one/two parents, number of older/younger siblings); 
measures of literacy attainment (as opposed to literary engagement); educational attainment of main care-giver and elements of multiculturalism within the home.

\section{School level factors}

Four school level factors were found to be related to the dependent variable. No significant differences were found between boys attending single sex schools and coeducational schools. For girls however there were differences, with girls in single sex schools more likely to display excess disengagement.

There was a moderate effect size for non-Catholic schools compared to Catholic schools, with non-Catholic schools associated with an increased risk of excess disengagement $(\mathrm{OR}=1.5,95 \% \mathrm{CI}=1.2-1.9)$. A significant, if modest, effect size was found for rural schools compared to urban schools $(\mathrm{OR}=1.1,95 \% \mathrm{CI}=1.0-1.3)$.

Other factors at the school level where no relationship was found were: school size; designated disadvantages status of a school; importance of Irish language/culture to the school ethos; number of non-teaching staff; the principals' levels of job satisfaction/stress and the principals' assessment of teachers' happiness and cooperation.

\section{Teacher (classroom) level factors}

Only one teacher level factor was found to be significantly related to the dependent variable. Attending classrooms where one teacher is required to teach two or more grades at the same time (multi-class teaching) was found to have a modest effect size $(\mathrm{OR}=1.2,95 \% \mathrm{CI}=1.0-1.3)$. Other factors were explored at this level, but none were found to be significantly related to the dependent variable. These factors included: teacher gender; teaching experience; teacher education (including basic and higher qualifications/ continuous professional development and in-service training); hours 
spent teaching Irish per week; teaching style adopted (active /traditional); assessment style adopted and various factors relating to teacher self-efficacy (control of teaching methods and syllabi, job satisfaction and stress, pupil discipline, feelings about student and colleagues happiness).

\section{Random effects}

The random effects at both the school and teacher levels were found to be statistically significant (estimated variance of the random effect distribution at school level=0.33, $\mathrm{p}$ value $=.0001$; estimated variance of the random effect distribution at teacher level $=0.26$, $\mathrm{p}$-value $=0.05)$. The significant random effects indicate the importance of individual characteristics at the teacher and school level which are not otherwise accounted for by the factors in the model. The effect sizes for these random effects depend on the individuals being compared. Using the middle $80 \%$ range as indicative of the population of possible effect sizes suggests that the random effects sizes vary between halving to doubling the odds of excess disengagement with Irish.

\section{Discussion}

This section explores the results of the analysis of the GUI data in the light of the literature on Irish language attainment and motivation to illustrate the current context for language policy decision-making in Ireland.

\section{Stable motivation for Irish}

While the findings about children's attitudes to Irish from the GUI study and Harris and Murtagh (1999) studies cannot be directly compared, it is useful to draw some inferences from the data in both, mapping the AMTB five point scale onto the GUI three point scale. In the 1985 study, almost half of children either strongly or slightly 
agreed with the statement "I really enjoy learning Irish". When the neutral group is brought in to combine the top three points on the five-point scale, that percentage rises to $58 \%$. The percentage of children who sometimes or always like Irish in the GUI study comes to $74 \%$. These results give an indication that perhaps motivation for Irish has remained largely stable since the 1980s. The NCCA review (2008) suggests that the introduction of the new communicative curriculum for Irish led to a more positive attitude to Irish among children. The GUI study suggests that there has at least been no major decline in children's attitudes and they may be comparable to attitudes among Welsh children to Welsh in a recent WISERD study (Pearse, 2015) and minority languages in Spanish autonomous regions (Huguet, 2006).

\section{Integration across languages}

The statistical model set out in the previous section integrated factors relating to language and cultural background of children and parents in order to explore the hypothesis that multilingualism could have a positive impact on attitudes towards Irish. However, this proved to be significant only in the case where the language in the home or the school is Irish, as might be expected from previous Irish studies (Murtagh, 2007) and studies of home (Huguet, 2006; Sánchez López \& Rodríguez de Tembleque, 1997) and school (Safont Jordà, 2007; Welsh Government Social Research, 2008) languages in other contexts . Children from diverse linguistic or cultural backgrounds did not exhibit a statistically significant difference in disposition towards the language. It is perhaps most noteworthy that there was no negative orientation to Irish among this population as has been posited in studies of similar minority language educational contexts in the Basque country (Ibarraran et al., 2008) and Catalunya (Bernaus, Masgoret, Gardner, \& Reyes, 2004). 
In relation to engagement with language skills, however, the findings suggest that children who are engaged with literacy pursuits, for example reading for pleasure, are more likely to be positively disposed towards Irish. This is particularly interesting given that the teaching and learning of Irish in English-medium schools in early primary school is predominantly oral. It is engagement, not achievement, with literacy which is related here, therefore Irish attitudes are not acting as a proxy for school success, as posited by Watson \& Nic Ghiolla Phádraig (2011). This finding possibly supports the notion that the integration of language skills across languages is valuable (Cummins and Ó Duibhir, 2012). This is of particular interest in the educational policy context in Ireland, where many schools have a multilingual student cohort. Integration of language skills between languages is one of the core principles of the new integrated primary language curriculum due to be operationalised in the $2015 / 2016$ academic year (Ó Duibhir \& Cummins, 2012). However, as evidenced by the 2011 discontinuation of a pilot initiative to introduce additional modern languages at primary school, the principle of achieving efficiencies by teaching for transfer across languages may be espoused but is not enacted in practice.

\section{School Patronage/ School Type}

In 2012 approximately $96 \%$ of Irish primary schools were under denominational, a fact that is remarkable and somewhat unique by international standards (Coolahan, Hussey, \& Kilfeather, 2012). Historical and cultural reasons underpin and maintain this denominational status while social, economic, cultural, demographic and educational changes are providing the impetus for change in primary school patronage to a more diverse and contemporary formation. Interestingly, it is not school ethos but school patronage which has a moderate statistically significant effect in relation to the attitudes of pupils towards Irish. This effect mirrors the findings of Ó Riagáin (2007) and Fahey 
et al. (2005) where non-Catholics in the Republic of Ireland are less likely than Catholics to claim strong competence in Irish or to associate speaking the Irish language with "Irishness". This effect is much more pronounced in Northern Ireland in previous studies. The data available for the Republic of Ireland on religion and attitudes to Irish derives from a 1999-2000 study (Pádraig Ó Riagáin, 2007) of adults. It is interesting that this effect persists among children in the 2007-8 GUI data.

The second effect of school patronage or school type relates to Irish-medium immersion schools where children are 3.3 times more likely to articulate a positive attitude towards Irish, in line with other minority language contexts noted in the previous section. Language rights have contributed to the growth and promotion of Irish language school patronage seeking to promote the provision of education through the medium of total immersion in the Irish language in Gaelscoileanna and Gaelcholaistí (i.e. Irish immersion post-primary schools), recognising parents' and children's rights to Irish language education provision.

To date, the foundation and establishment of Gaelscoileanna and Gaelcholáistí has been centred around urban areas where a critical mass of parental demand has been recognised by the Department of Education and Skills. Gaelscoileanna/ Gaelcholáistí patrons aim to foster and develop an Irish language community aimed at promoting the Irish language as a means of communication. Given that the changes in patronage and emergence of greater number of Gaelscoileanna are relatively recent, the development of an established and sustainable Irish speaking community outside of Gaeltacht areas is in its infancy. A small number of Gaelscoileanna and Gaelcholáistí have existed for a considerable length of time in urban areas which may contribute to the positive effect of urban settings on attitudes to Irish. However, the establishment of a community 
background effect could take anything up to 14 years based on a child's time in primary and post-primary school.

In this study, the effect of the Gaelscoil is far more pronounced than that of the Gaeltacht school. A number of recent studies have articulated current challenges in Gaeltacht areas in relation to the linguistic complexity facing the Gaeltacht schools (Mac Donnacha, S., Ní Chualáin, F., Ní Sheaghdha, A., \& Ní Mhainín, T., 2005; Ó Giollagáin \& Mac Donnacha, 2008). This is perhaps reflected in this study in the attenuated positive disposition of Gaeltacht school pupils relative to their Gaelscoil peers.

\section{Teacher and School Random Effects}

An interesting if somewhat unexpected finding from this study relates to the random effects of teachers and schools on children's engagement with Irish. For many children their only interaction with Irish is in the classroom (Murtagh, 2007), as in other minority language contexts to varying degrees (Vila, 2014; Welsh Government Social Research, 2008). The importance of effective language teaching methodologies for the development of competencies and a positive attitude towards Irish has been widely documented (Harris, Forde, Archer, Nic Fhearaile, \& O'Gorman, 2006a) and is the basis for most national policy. The GUI data provides a very rich dataset in relation to teaching, learning and assessment methodologies used by teachers in the classroom. The use of group work for example has been noted as related to general school engagement (McCoy et al., 2012). However, no teaching related variable emerges as related to engagement with Irish. As the variables related to teaching approach are not subject specific, this could be explained by the fact that the GUI teacher survey does not elicit pedagogical content knowledge necessary for effective language teaching. It is 
also possible that the methodologies reported by teachers in general classroom use are not those implemented during Irish lesson time. Indeed as noted above in the 2007 Inspectorate report, in up to $50 \%$ of Irish lessons observed the quality of teaching and learning was not satisfactory (Inspectorate, Department of Education and Science, 2007).

In the light of these negative findings, the significance of teacher and school level random effects strongly suggests that it is not teaching methodologies which impact on children's engagement with Irish but rather some dimension of the teacher and of the school not otherwise captured in the data. The notion that the teacher plays a critical role in establishing and maintaining motivation for language learning is well established (Dörnyei, 2010). What is interesting in the current study however, is that a range of teacher variables relating to teacher demographics, teacher education, teaching style and teacher self-efficacy are not statistically significant as regards excess disengagement with the Irish language. As stated by Harris (2007):

Irish depends on the attitudes, efforts and commitment of individual schools and teachers in a way that other subjects do not. By the same token, changes in teachers' attitudes, motivation, self-esteem, or professional satisfaction in teaching are also of greater significance in the case of Irish. (Harris, 2007, pp.37-38)

Given the importance of the teacher within the motivational cycle for Irish, the findings of Harris (2006) in relation to the downward trajectory of both attitudes and competencies of primary school teachers in relation to Irish are particularly worrying. Furthermore, while studies of student teacher attitudes to Irish are largely positive (CILAR 1975; Ó Riagáin \& Ó Gliasáin, 1983, 1993; Ó Laoire, 2007), the impact of 
this positivity in the classroom is questionable as the positivity seems to be "passive stance rather than proactive attitude" (Ó Laoire, 2007, p. 181). The literature on language teacher cognition emphasises that what teachers do in the classroom is aligned with what they know, and also importantly with their beliefs (Borg, 2003; Devine et al 2013). Furthermore, studies have shown that it is possible to impact on beliefs and therefore practice as part of pre-service and in-service teacher education (Borg, 2011). In this context, the need to address teachers' beliefs and attitudes in relation to Irish, as well as their use and knowledge of language teaching methodologies as part of the continuum of teacher education becomes critical.

Interestingly however, Harris (2006) also found that teachers were increasingly influenced by school and national policy as to the emphasis they place on the language in the classroom. From a negative perspective, this might suggest that teachers are less personally invested in the language than formerly. Conversely, this might suggest that policy interventions may translate more readily to classroom practice, given the appropriate professional supports (Fullan \& Hargreaves, 1992).

\section{Conclusions}

The study presented here adds an empirically grounded dimension to the current linguistic landscape which suggests motivation to learn Irish is notably stable among 9 year olds. The development of children's attitudes from primary into post-primary education will be explored in future work in a comparison of the child cohort data at 9 years (GUI wave 1) and 13 years (GUI wave 2). In the 9 year old cohort, engagement is strongest in the Gaelscoil setting but in schools more generally it is critically dependent on the classroom teacher. In a context of reducing motivation and proficiency among teachers, this is not a sustainable position and certainly not one upon which to base a 
language revival as envisaged in the 20-Year Strategy (Government of Ireland, 2010). This study would indicate that a focus on teacher attitudes towards Irish, in addition to their teaching competencies, at pre-service and in-career could impact positively on children's engagement with Irish. Furthermore, the findings regarding the interaction between engagement with literacy and with Irish would support the notion of a fully integrated language curriculum at primary level, in the sense set out in the work of Cummins and Ó Duibhir (2012). Similarly, it would suggest the current terms of reference for an emerging national language policy which excludes Irish and primary education are flawed, as integration across languages at primary school appears to have a positive effect on engagement in this study. Perhaps the most important finding however is the disassociation of motivational factors for Irish from a broad range of child-related factors with the exception of those related to the school environment. In the context of a 20-year strategy for Irish which aims to shift the locus for the language from the school to the wider community, it is clear that there is major work to be done. At the time of the data collection of this GUI study, the strategy was not active. Its partial activation since that time may be positive in terms of policy implementation, if not in terms of measured outcomes as yet.

Welsh and Catalan are often put forward of examples of successful language revitalisation and maintenance (Johnson, 2013; Vila, 2014). In both cases, while the education system is a key driver in this success what is of crucial importance is the mobilisation of grassroots support not only to generate demand for bilingual educational opportunities but also to establish an authentic context for use of the language outside the school walls. While the demand for bilingual education in Ireland is strong and increasing, the struggle remains here, as in other minority language contexts including 
Wales and Catalunya (Vila, 2014), to establish an authentic context for use outside the education system.

\section{References}

Bernaus, M., Masgoret, A.-M., Gardner, R. C., \& Reyes, E. (2004). Motivation and Attitudes Towards Learning Languages in Multicultural Classrooms. International Journal of Multilingualism, 1(2), 75-89. http://doi.org/10.1080/14790710408668180

Committee on Irish Language Attitudes Research (CILAR). (1975). Report. Dublin: Stationery Office.

Conrick, M. (2009). Citizenship and Language Issues: the interface between language policy and planning and linguistic diversity. Canadian Journal of Irish Studies, $35(1), 25-31$.

Coolahan, J., Hussey, C., \& Kilfeather, F. (2012). The Forum on Patronage and Pluralism in the Primary Sector.

CSO. (2011). Census 2011 Profile 9 What We Know - Education, skills and the Irish language. (Central Statistics Office). Retrieved from http://www.cso.ie/en/census/census2011 reports/census2011profile9whatwekno w-educationskillsandtheirishlanguage/

Cummins, J. (1979). Cognitive/Academic language proficiency, linguistic interdependence, the optimum age question and some other matters. Working Papers on Bilingualism, 19, 197-205.

Dörnyei, Z. (2001). Motivational Strategies in the Language Classroom. Cambridge: Cambridge University Press.

Dörnyei, Z. (2005). The Psychology of the Language Learner: Individual Differences in Second Language Acquisition (1 edition). New York, NY: Routledge. 
Dörnyei, Z., \& Csizér, K. (1998). Ten commandments for motivating language learners: results of an empirical study. Language Teaching Research, 2(3), 203-229. http://doi.org/10.1177/136216889800200303

Ellis, R. (1997). SLA research and language teaching. Oxford: Oxford University Press.

Fahey, T., Hayes, B. C., \& Sinnott, R. (2005). Conflict and Consensus: A Study of Values and Attitudes in the Republic of Ireland and Northern Ireland. Institute of Public Administration.

Fullan, M., \& Hargreaves, A. (1992). Teacher Development and Educational Change. Psychology Press.

Government of Ireland. (2010). 20 Year Strategy for Irish 2010-2030. Dublin:

Government of Ireland. Retrieved from

http://www.ahg.gov.ie/ie/Straiteis20BliaindonGhaeilge2010-

2030/Foilseachain/Strait\%C3\%A9is\%2020\%20Bliain\%20-

\%20Leagan\%20Gaeilge.pdf

Green, S., Williams, J., Latye, R., Doyle, E., Harris, E., McCrory, C., ... Whelan. (2010). Growing Up in Ireland: Background and Conceptual Framework. Dublin: The Stationery Office.

Harris, J. (2007). Bilingual Education and Bilingualism in Ireland North and South. International Journal of Bilingual Education and Bilingualism, 10(4), 359-368. http://doi.org/10.2167/beb449.0

Harris, J., Forde, P., Archer, P., Nic Fhearaile, S., \& O'Gorman, E. (2006a). Irish in primary-schools: Long-term national trends in achievement. Dublin: Department of Education and Science. 
Harris, J., Forde, P., Archer, P., Nic Fhearaile, S., \& O’Gorman, M. (2006b). Irish in primary schools: long-term national trends in achievement. Dublin: Stationery Office.

Harris, J., \& Murtagh, L. (1999). Teaching and Learning Irish in Primary School: A Review of Research and Development. ERIC.

Hornberger, N. H. (2004). The Continua of Biliteracy and the Bilingual Educator: Educational Linguistics in Practice. International Journal of Bilingual Education and Bilingualism, 7(2-3), 155-171. http://doi.org/10.1080/13670050408667806

Huguet, Á. (2006). Attitudes and Motivation Versus Language Achievement in Crosslinguistic Settings. What is Cause and What Effect? Journal of Multilingual and Multicultural Development, 27(5), 413-429. http://doi.org/10.2167/jmmd426.1

Ianos, M.-A., Huguet, Á., Janés, J., \& Lapresta, C. (2015). Can language attitudes be improved? A longitudinal study of immigrant students in Catalonia (Spain). International Journal of Bilingual Education and Bilingualism, O(0), 1-15. http://doi.org/10.1080/13670050.2015.1051508

Ibarraran, A., Lasagabaster, D., \& Sierra, J. M. (2008). Multilingualism and Language Attitudes: Local Versus Immigrant Students’ Perceptions. Language Awareness, 17(4), 326-341. http://doi.org/10.1080/09658410802147311

Inspectorate, Department of Education and Science. (2007). Irish in the primary school. Dublin: Inspectorate, Evaluation Support \& Research Unit.

Inspectorate, Department of Education and Skills. (2013). Chief Inspector's Report 2010-2012. Dublin: Inspectorate of the Department of Education and Skills. 
Jimerson, S. R., Campos, E., \& Greif, J. L. (2014). Toward an Understanding of Definitions and Measures of School Engagement and Related Terms. The California School Psychologist, 8(1), 7-27. http://doi.org/10.1007/BF03340893

Johnson, D. C. (2013). Language Policy. Palgrave Macmillan.

Laoire, M. Ó. (2007). An Approach to Developing Language Awareness in the Irish Language Classroom: A Case Study. International Journal of Bilingual Education and Bilingualism, 10(4), 454-470. http://doi.org/10.2167/beb454.0

Lasagabaster, D., \& Huguet, A. (2007). Multilingualism in European Bilingual Contexts: Language Use and Attitudes. Multilingual Matters.

Lightbown, P. M., \& Spada, N. (2001). How languages are learned. Oxford, U.K.: Oxford University Press.

Littlewood, W. (1984). Foreign and Second Language Learning: Language acquisition research and its implications for the classroom. Cambridge: Cambridge University Press.

Mac Donnacha, S., Ní Chualáin, F., Ní Sheaghdha, A., \& Ní Mhainín, T. (2005). Staid Reatha na Scoileanna Gaeltachta 2004: Achoimre. Baile Átha Cliath: An Chomhairle um Oideachas Gaeltachta agus Gaelscolaíochta.

Martin-Jones, M. (2009). From life worlds and work worlds to college: The bilingual literacy practices of young Welsh speakers. The Welsh Journal of Education, $14(2), 45-62$.

McCoy, S., Smyth, E., \& Banks, J. (2012). The primary classroom: Insights from the growing up in Ireland study. Dublin: ESRI.

Molenberghs, G., \& Verbeke, G. (2007). Likelihood Ratio, Score, and Wald Tests in a Constrained Parameter Space. The American Statistician, 61(1), 22-27. 
MORI Ireland. (2005). Turning on and Tuning in to Irish Language Radio in the 21st Century. Dublin, Ireland: MORI Ireland. Retrieved from https://www.ipsosmori.com/Assets/Docs/Archive/Polls/irish_language_survey_jan_05.pdf

Murtagh, L. (2007). Out-of-school Use of Irish, Motivation and Proficiency in Immersion and Subject-only Post-primary Programmes. International Journal of Bilingual Education and Bilingualism, 10(4), 428-453. http://doi.org/10.2167/beb453.0

National Council for Curriculum and Assessment. (1999). Gaeilge teanga: curaclam. Baile Átha Cliath: Oifig an tSoláthair.

National Council for Curriculum and Assessment. (2008). Primary curriculum review, Phase 2: Final report and recommendations. Dublin: National Council for Curriculum and Assessment.

Ó Duibhir, P., \& Cummins, J. (2012). Towards an Integrated Language Curriculum in Early Childhood and Primary Education (3-12 years). Dublin: NCCA.

Ó Giollagáin, C., \& Mac Donnacha, S. (2008). The Gaeltacht Today. In C. Nic Pháidín \& S. Ó Cearnaigh (Eds.), A New View of the Irish Language. Dublin: Cois Life. Ó Riagáin, P. (2007). Relationships between Attitudes to Irish, Social Class, Religion and National Identity in the Republic of Ireland and Northern Ireland. International Journal of Bilingual Education and Bilingualism, 10(4), 369-393. http://doi.org/10.2167/beb450.0

Ó Riagáin, P., \& Ó Gliasáin, M. (1984). The Irish Language in the Republic of Ireland 1983: Preliminary Report of a National Survey. Dublin: Institiúid Teangeolaíochta Éireann.

Ó Riagáin, P., \& Ó Gliasáin, M. (1994). National Survey on Languages 1993: Preliminary Report. Dublin: Institiúid Teangeolaíochta Éireann. 
Parsons, C. E., \& Lyddy, F. (2015). A longitudinal study of early reading development in two languages: comparing literacy outcomes in Irish immersion, English medium and Gaeltacht schools. International Journal of Bilingual Education and Bilingualism, O(0), 1-19. http://doi.org/10.1080/13670050.2015.1019412

Pearse, S. (2015). What future for the Welsh language in Wales. Presented at the WISERD Annual Conference, Cardiff, UK. Retrieved from http://www.wiserd.ac.uk/files/1014/4000/4282/Conf2015D2S3Devo_FutureWel shLanguageWales.pdf

Safont Jordà, M. P. (2007). Language Use and Language Attitudes in the Valencian Community. In D. Lasagabaster \& Á. Huguet (Eds.), Multilingualism in European Bilingual Contexts: Language Use and Attitudes. Clevedon, UK: Multilingual Matters.

Sánchez López, M. P., \& Rodríguez de Tembleque, R. (1997). El bilingüísmo : bases para la intervención psicológica. Madrid: Síntesis.

Stram, D. O., \& Lee, J. W. (1994). Variance Components Testing in the Longitudinal Mixed Effects Model. Biometrics, 50(4), 1171-1177.

Ushioda, E. (1996). Learner Autonomy 5: The role of motivation. Dublin: Authentik. Vila, X., F. (2014). Promoting language use in the school environment: some lessons from the Catalan-speaking regions. Vitoria-Gasteiz: Departamento de Educación, Política Lingüística y Cultura del Gobierno Vasco. Retrieved from https://www.academia.edu/9825026/Promoting_language_use_in_the_school_e nvironment_some_lessons_from_the_Catalan-speaking_regions

Watson, I., \& Nic Ghiolla Phádraig, M. (2011). Linguistic Elitism: the Advantage of Speaking Irish Rather than the Irish-speaker Advantage. The Economic and Social Review, 42(4), 437-454. 
Welsh Government Social Research. (2008). Evaluation of the Immersion and Intensive Language Teaching Pilot Projects. Cardiff: Welsh Government Social Research.

Williams, M., \& Burden, R. L. (1997). Psychology for language teachers : a social constructivist approach. Cambridge: Cambridge University Press. 
Table 1. Parameter estimates from ordinal logistic regression mixed model for factors related to excess disengagement with Irish.

Factor

Likes school (ref: always)

sometimes $\quad 0.848$
never $\quad 1.657$

Likes teacher (ref: always)

$\begin{array}{rr}\text { sometimes } & 0.456 \\ \text { never } & 0.972 \\ \text { don't know } & 0.690\end{array}$

Likes reading (ref: always)

sometimes $\quad 0.555$

never $\quad 0.937$

Likes mathematics (ref: always)

$$
\begin{array}{rr}
\text { sometimes } & 0.146 \\
\text { never } & 0.128
\end{array}
$$

\section{Language medium of School} (ref: English)

Multilingual Home

$$
\begin{array}{cc}
\text { Gaelscoil } & -1.194 \\
\text { Gaeltacht } & -0.623
\end{array}
$$

(ref: Irish spoken in home)

$$
\text { other language(s) spoken }
$$

Irish and other language(s) spoken

0.329

0.461

Reads for fun (ref: everyday)

a few times a week

0.012 once a week

0.161

less than weekly

Reads with parents, yes/no (ref:

yes)

Screen time (ref: more than 3

hours/day)

$$
\begin{aligned}
& \text { no more than } 1 \text { hour } \\
& \text { no more than } 2 \text { hours } \\
& \text { no more than } 3 \text { hours }
\end{aligned}
$$

$-0.127$

Resource hours allocated, yes/no

$-0.110$

0.106

(ref: no)

0.359

0.122

$0.14 \quad 0.00$

$0.19 \quad 0.08$

1.4

$0.08 \quad 0.00$

Interaction:

likes mathematics - resource hours

$$
\begin{array}{rr}
\text { sometimes }- \text { yes } & 0.516 \\
\text { never }- \text { yes } & 0.535
\end{array}
$$

School gender mix (re: $\begin{array}{lll}0.05 & 0.82 & 1.0\end{array}$

$\begin{array}{lll}0.08 & 0.04 & 1.2\end{array}$

$\begin{array}{lll}0.08 & 0.00 & 1.4\end{array}$

$\begin{array}{lll}0.05 & 0.01 & 1.1\end{array}$

$\begin{array}{lll}0.07 & 0.00 & 0.7\end{array}$

$\begin{array}{lll}0.07 & 0.08 & 0.9\end{array}$

$\begin{array}{lll}0.06 & 0.05 & 0.9\end{array}$

$0.11 \quad 0.33$

1.1

$0.16 \quad 0.00$

$0.26 \quad 0.04$ coeducational) 
Interaction:

all boys $\quad-0.039$

all girls $\quad 0.160$
$0.11 \quad 0.71$

$0.11 \quad 0.13$
1.0

1.2

likes mathematics - school

gender mix

$$
\begin{array}{r}
\text { sometimes - all boys } \\
\text { never - all boys } \\
\text { sometimes - all girls } \\
\text { never - all girls }
\end{array}
$$

0.213

0.14

0.12

1.4

0.162

0.26

0.53

1.3

0.070

$0.13 \quad 0.61$

1.4

0.751

0.25

0.00

2.8

School patronage, catholic/noncatholic

(ref: catholic)

0.405

$0.12 \quad 0.00$

1.5

Region, rural/urban (re: rural)

0.131

$0.06 \quad 0.03$

1.1

Multilcass teaching, yes/no (ref: yes)

0.140

$0.06 \quad 0.03$

1.2 